Tropical Journal of Pharmaceutical Research December 2015; 14 (12): 2223-2229

ISSN: $1596-5996$ (print); 1596-9827 (electronic)

(c) Pharmacotherapy Group, Faculty of Pharmacy, University of Benin, Benin City, 300001 Nigeria.

All rights reserved.

Available online at http://www.tjpr.org

Original Research Article

http://dx.doi.org/10.4314/tjpr.v14i12.11

\title{
Development of Vanadometric System for Spectrophotometric Determination of Timolol in Pure and Dosage Forms
}

\author{
Charles O Nnadi ${ }^{1 \star}$, Wilfred O Obonga ${ }^{1}$, John DN Ogbonna ${ }^{2}$ and Linus O Ugwu ${ }^{3}$ \\ ${ }^{1}$ Department of Pharmaceutical and Medicinal Chemistry, ${ }^{2}$ Department of Pharmaceutics, ${ }^{3}$ Department of Veterinary Medicine, \\ University of Nigeria, Nsukka, 410001, Nsukka
}

*For correspondence: Email: chasnnadi@yahoo.com; Tel: +2348064947734

Received: 25 December 2014

Revised accepted: 30 September 2015

\begin{abstract}
Purpose: To develop a simple vanadometric spectrophotometric method for the assay of timolol. Methods: The oxidation reactions were performed at optimum conditions of $3 \mathrm{~mL} 20 \% \mathrm{v} / \mathrm{v} \mathrm{H}_{2} \mathrm{SO}_{4}, 6.5$ $\% \mathrm{w} / \mathrm{v}$ ammonium metavanadate, $40-60^{\circ} \mathrm{C}$ and $5 \mathrm{~min}$ for full colour (blue) development. The proposed method was validated in accordance with International Council on Harmonization (ICH) guidelines Q2 (R1) and applied to assay commercial timolol.

Results: Oxidation of timolol occurred at $504 \mathrm{~nm}$ wavelength. The developed method recovered 99.25 $102.00 \%$ of timolol in pre-analyzed formulations and $99.85-102.00 \%$ of the manufacturers' claim in commercial samples with $R S D<2 \%$. Linearity of $2-20 \mathrm{ppm}\left(R^{2}=0.9995\right)$, as well as accuracy, 98 $101 \%$; precision, $0.98 \%$ (intraday) and $1.25 \%$ (interday); robustness, $0.95 \%$; LOD, 0.256 ppm; LOQ, 0.425 ppm; and robustness, $0.95-1.10 \%$, were obtained.

Conclusion: The developed method is simple, sensitive, low-cost, accurate, reproducible, robust and rugged, and compares well with some complex methods for assay of timolol maleate in pure and dosage forms.
\end{abstract}

Keywords: Ammonium metavanadate, Spectrophotometry, Vanadometric, Timolol

\begin{abstract}
Tropical Journal of Pharmaceutical Research is indexed by Science Citation Index (SciSearch), Scopus, International Pharmaceutical Abstract, Chemical Abstracts, Embase, Index Copernicus, EBSCO, African Index Medicus, JournalSeek, Journal Citation Reports/Science Edition, Directory of Open Access Journals (DOAJ), African Journal Online, Bioline International, Open-J-Gate and Pharmacy Abstracts
\end{abstract}

\section{INTRODUCTION}

Transition element-based compounds have great potentials in quality control (QC) of pharmaceuticals due to the presence of lone electron pair(s), and the consequent ability to form complexes with many drugs. Ammonium metavanadate (AMV) is a yellow crystalline solid that has been used variously as a catalyst for alpha-hydroxyphosphonate [1], insulin mimic [2], oxidizer and sensor for $\mathrm{N}$-acetyltransferase activity in urine analysis post-isoniazid administration [3] and is known to exhibit pHdependent variable oxidative states of +5 to +2 due to $3 \mathrm{~d} 34 \mathrm{~s} 2$ configuration of central vanadium with colour variations in solution of reductants [4]. These unique properties of AMV have been utilized in the analysis of many pharmaceutical dosage forms and inorganic cations.

Timolol maleate (Scheme 1) is a first generation non-selective beta-adrenergic receptor antagonist used in the treatment of myocardial infarction, migraine, chronic open-angle glaucoma, heart attack, angina pectoris and ocular hypertension [5]. It is chemically designated as (S)-1-[(1, 1-dimethylethyl) amino]3-[[4-(4-morpholinyl)-1, 2, 5-thiadiazol-3-yl] oxy]- 
2-propanol (Z)-2-butenedioate (1:1) salt. Timolol, in combination with a diuretic, has remained the first line drug of choice in a stepped-care approach to anti-hypertensive drug therapy and has remained among the top prescribed agents for management of cardiac disorders among the blacks.

The therapeutic importance of timolol necessitated development of spectrophotometric [6-10], HPLC [11], HPTLC [12], chemiluminescence [13], voltammetric [14], electrophoretic [15], TLC densitometric [16], complexometric by charge transfer [17], RPHPLC [18-21] and LC [22] methods for its determination in single dosage and/or combined forms by analysts. Most of the reported methods require complex instrumentation; delicate sample preparation methods, costly reagents, expertise and a lot of time.

Literature survey indicated no report(s) of developed vanadometric assay method for timolol in single or combined forms. Against this backdrop, we developed and validated an oxidometric spectrophotometric assay method for timolol, applied the developed validated method for assay of the drug in a single dosage form and compared the validation parameters with the earlier developed methods of assay. Attempts were also made to propose the possible route and mechanisms of oxidation; the principle of which the developed method is dependent.

\section{EXPERIMENTAL}

\section{Materials}

Whatman $0.2 \mu \mathrm{m}$ membrane filter, $25 \mu \mathrm{mm}$ diameter size (Cole-Palmer, Nigeria), U-2900 double beam UV-visible spectrophotometer, 190 - $1100 \mathrm{~nm}, 1.5 \mathrm{~nm}$ spectral bandpass (Hitachi High-Tech Co, Japan). All the reagents are of analytical grade. All the timolol formulations $(0.25$ and $0.5 \%$ ) used were procured from reputable drug outlets and were still within their expiry date.

\section{Methods}

\section{Optimization of experimental variables}

The effect of AMV concentration was determined by adding aliquot $1.0 \mathrm{~mL}$ of $0.5-10 \% \mathrm{w} / \mathrm{V} \mathrm{AMV}$ to equal volume $(1 \mathrm{~mL})$ of $2.5 \mathrm{ppm}$ timolol in different test tubes. The nature and concentration of acidic medium $\left(\mathrm{H}_{2} \mathrm{SO}_{4}, \mathrm{HCl}, \mathrm{HNO}_{3}, \mathrm{H}_{3} \mathrm{PO}_{4}\right.$ and $\mathrm{HClO}_{3}$ ) were studied by adding various volumes $(0.5-6 \mathrm{~mL})$ of concentrated acids and the optimum concentration of oxidant to $2.5 \mathrm{ppm}$ timolol solution. Optimum temperature was determined by carrying out the reaction in a thermostatically controlled water bath at different temperatures 25 - $100{ }^{\circ} \mathrm{C}$ at the optimum conditions so far determined, while the reaction time was studied for different periods of time (060 mins). The stability of the developed colour was studied up to $4 \mathrm{~h}$, while the order of addition of AMV, acid, and temperature to the drug solution were determined appropriately. For each variable, the rate of blue colour development and the absorbance values recorded at $504 \mathrm{~nm}$ were used as parameter for selecting optimum condition for the analysis.

\section{General timolol assay method}

The standard timolol solution (1 $\mathrm{mL})$ was transferred into $10 \mathrm{~mL}$ calibrated flask and $1 \mathrm{~mL}$ of the $6.5 \% \mathrm{w} / \mathrm{v}$ AMV was added. The optimum volume $(3 \mathrm{~mL})$ of $20 \% \mathrm{v} / \mathrm{v}$ of $\mathrm{H}_{2} \mathrm{SO}_{4}$ was added (Table 1). The contents of the flasks were thoroughly mixed and the reactions were allowed to proceed for different periods of time (Table 1) at different temperature $\left(40-60{ }^{\circ} \mathrm{C}\right)$, and then cooled to room temperature. After completion of the reactions, the solutions were completed to volume with distilled water. The absorbance of the resulting solutions was measured at the $\lambda_{\max }$ of $504 \mathrm{~nm}$ against reagent blanks treated similarly.

\section{Method validation}

The proposed method was validated in accordance with the ICH guidelines Q2 (R1) for linearity, precision, accuracy, limits of detection and quantization, interference, ruggedness and robustness [9]. The linearity was determined by preparing six replicates of standard solution of timolol in the range of 2-20 ppm and the construction of standard calibration curves using the optimum conditions. Regression analysis was carried out using least square method. Precision was determined by replicate analysis of nine different solutions of timolol at $10 \mathrm{ppm}$ and estimating the relative standard deviation, RSD. Robustness was determined by carrying out the reaction at temperature of $40{ }^{\circ} \mathrm{C}$ instead of 50 ${ }^{\circ} \mathrm{C}$, and then $5 \% \mathrm{w} / \mathrm{v}$ AMV instead of $6.5 \% \mathrm{w} / \mathrm{v}$ to ascertain the influences of AMV concentration and temperature variations (or any other parameter) on the performance of the proposed method while keeping other optimum conditions unchanged. The percentage recovery and the RSD were determined. Ruggedness was performed by carrying out the analysis on different days and using two different spectrophotometers in different laboratories. The percentage recovery and \% RSD were 
determined for day-to-day and laboratorylaboratory assay. The limit of detection (LOD) and limit of quantitation (LOQ) were determined using the formula 3S/slope and 10S/slope respectively, where $S$ is the standard deviation of the intercept of the Beer's calibration.

\section{Recovery studies}

Recovery studies were carried out by adding a $10 \mathrm{ppm}$ solution of pre-analyzed timolol eye-drop to standard solution of pure timolol at 80,100 and $120 \%$ levels [6]. To $1 \mathrm{~mL}$ of pre-analyzed eye-drop solution in three different test tubes, $0.8,1.0$ and $1.2 \mathrm{~mL}$ of $10 \mathrm{ppm}$ standard solution were added to each of the eye-drop solution respectively and then $1 \mathrm{~mL} A M V+3 \mathrm{~mL}$ sulphuric acid. The solutions were diluted to 10 $\mathrm{mL}$ volume and assayed.

\section{Analysis of timolol formulations by proposed method}

A quantity of eye-drop equivalent to $1 \mathrm{mg}$ of timolol was accurately measured and transferred into a $10 \mathrm{~mL}$ volumetric flask, appropriately diluted with $1 \mathrm{~mL} 6.5 \% \mathrm{w} / \mathrm{v}$ AMV and $3 \mathrm{~mL} 20 \%$ $\mathrm{v} / \mathrm{v}$ of sulphuric acid, made up to mark with distilled water and then warmed to the required temperature and allowed some time for colour development to finally produce a sample solution for UV/VIS spectrophotometric analysis as already described. The amount of drug present in the sample solution was determined using the regression equation of calibration curve of standard [8].

\section{RESULTS}

The preliminary findings (Table 1) showed that the absorption intensity of timolol increased progressively with increasing concentration of AMV and $\mathrm{H}_{2} \mathrm{SO}_{4}$, reaction time and temperature until the maximum absorbance was obtained. However, further increase in the concentration of AMV or acid, temperature or time had no effect on the absorbance.

The parameters selected as optimum conditions (Table 1) were considered as the parameter (concentration, time and temperature) at which maximum absorbance was obtained or full colour development observed in the near plateau region of the parameter-absorbance curves.

Table 1: Optimization of experimental variables

\begin{tabular}{lc}
\hline Parameter & Value \\
\hline AMV concentration & $6.5 \% \mathrm{w} / \mathrm{v}$ \\
Concentration and nature of acid & $20 \% \mathrm{v} / \mathrm{v}, \mathrm{H}_{2} \mathrm{SO}_{4} 3 \mathrm{~mL}$ \\
Temperature & $40-60 \pm 0.4-1.6{ }^{\circ} \mathrm{C}$ \\
Reaction Time & $5.0 \pm 0.6$ mins \\
Complex stability & $3.4 \pm 0.9$ hours \\
Order of addition & Drug $=\mathrm{AMV}^{>} \mathrm{H}_{2} \mathrm{SO}_{4}>$ Time $=$ Temperature \\
\hline
\end{tabular}

*Values are mean $\pm S D$

Table 2: Parameters of the proposed method validation

\begin{tabular}{lccc}
\hline Parameter & Value & Parameter & Value \\
\hline$\Lambda_{\max }$ & $504 \mathrm{~nm}$ & Precision & \\
$\mathrm{R}^{2}$ & 0.9995 & Intra-day (\% RSD) & $0.98 \%$ \\
Slope & 0.665 & Inter-day (Ruggedness) & $1.250-1.251 \%$ \\
Intercept & 0.0015 & Accuracy (Recovery) & $98-101 \%$ \\
Beer's limit (Linearity) & $2-20 \mu \mathrm{g} / \mathrm{mL}$ & Robustness $\%$ RSD) & $0.95-1.10 \%$ \\
LOD $(\mu \mathrm{g} / \mathrm{mL})$ & $0.256-0.921$ & LOQ $(\mu \mathrm{g} / \mathrm{mL})$ & $0.425-1.611$ \\
\hline
\end{tabular}

Table 3: Recovery of timolol from pre-analyzed eye-drops

\begin{tabular}{cccc}
\hline Formulation & $\begin{array}{c}\text { Amount of } \\
\text { timolol spiked (\%) }\end{array}$ & Amount recovered (\%) & \% RSD \\
\hline Eye-drop A & 80 & $99.25 \pm 1.03$ & 1.28 \\
& 100 & $100.60 \pm 0.94$ & 0.96 \\
Eye-drop B & 120 & $101.90 \pm 0.29$ & 0.11 \\
& 80 & $102.00 \pm 0.78$ & .082 \\
Eye-drop C & 100 & $99.80 \pm 1.00$ & 1.01 \\
& 120 & $99.50 \pm 1.01$ & 1.05 \\
& 80 & $100.05 \pm 0.47$ & 0.66 \\
& 100 & $100.70 \pm 0.39$ & 0.13 \\
& 120 & $99.70 \pm 1.29$ & 1.90 \\
\hline
\end{tabular}


Table 4: Analysis of commercial formulations of timolol

\begin{tabular}{lccccc}
\hline Formulation & $\begin{array}{c}\text { Label claim } \\
(\mathbf{m g} / \mathbf{m L})\end{array}$ & $\begin{array}{c}\text { Amount estimated } \\
(\mathbf{m g} / \mathbf{m L})\end{array}$ & $\begin{array}{c}\text { Estimated } \\
(\%)\end{array}$ & $\%$ RSD & SD \\
\hline Eye-drop A & 2.5 & 2.541 & 101.65 & 1.56 & 1.86 \\
Eye-drop B & 2.5 & 2.496 & 99.85 & 0.87 & 0.98 \\
Eye-drop C & 5.0 & 5.100 & 102.00 & 1.85 & 1.90 \\
\hline
\end{tabular}

\section{DISCUSSION}

The stability of the complex was observed beyond $3.4 \mathrm{~h}$ which is an indication that this assay could be done for a longer time than usual, thereby providing flexibility of the method in cases of large scale assay in QC. The order of addition was performed to determine effect sequence of inclusion of the parameters during timolol assay. The result showed that the acidic medium should be created first once the drug comes in contact with the oxidant before adjusting the time or the temperature or both. Other acids did not provide intense colour development compared to $\mathrm{H}_{2} \mathrm{SO}_{4}$.

The result of method validation showed that Beer's law was obeyed at 2 - 20 ppm concentration with good correlation coefficient (0.9995). The RSD was less than $2 \%(0.98 \%)$ signifying good reproducibility of the proposed method for routine timolol assay. The percentage recovery of timolol was $98-101 \%$ while the \%
RSD was $1.1 \%$. Variations of optimum parameters did not affect the recovery and RSD significantly showing the reliability and flexibility of the proposed method of timolol analysis. The $\%$ RSD obtained for lab-to-lab and day-to-day assay were 1.25 and 1.251 respectively showing the reproducibility of the proposed method.

Timolol is a morpholine ring-containing (A) $\beta$ adrenoceptor antagonist. Cleavage of the morpholine ring constitutes one of the major oxidation pathways, aside S-oxidation of thiadiazole ring (B) as shown in Scheme 1.

The morpholine cleavage involves two pathways(I) initial oxidative attack on one of the carbon atoms adjacent to the nitrogen atom of the morpholine ring forming hydroxyl-ether intermediates and the timolol ethanolamine and (II) cleavage of the morpholine ring of timolol occurs prior to oxidative attack at one of the carbon atoms adjacent to the oxygen atom;

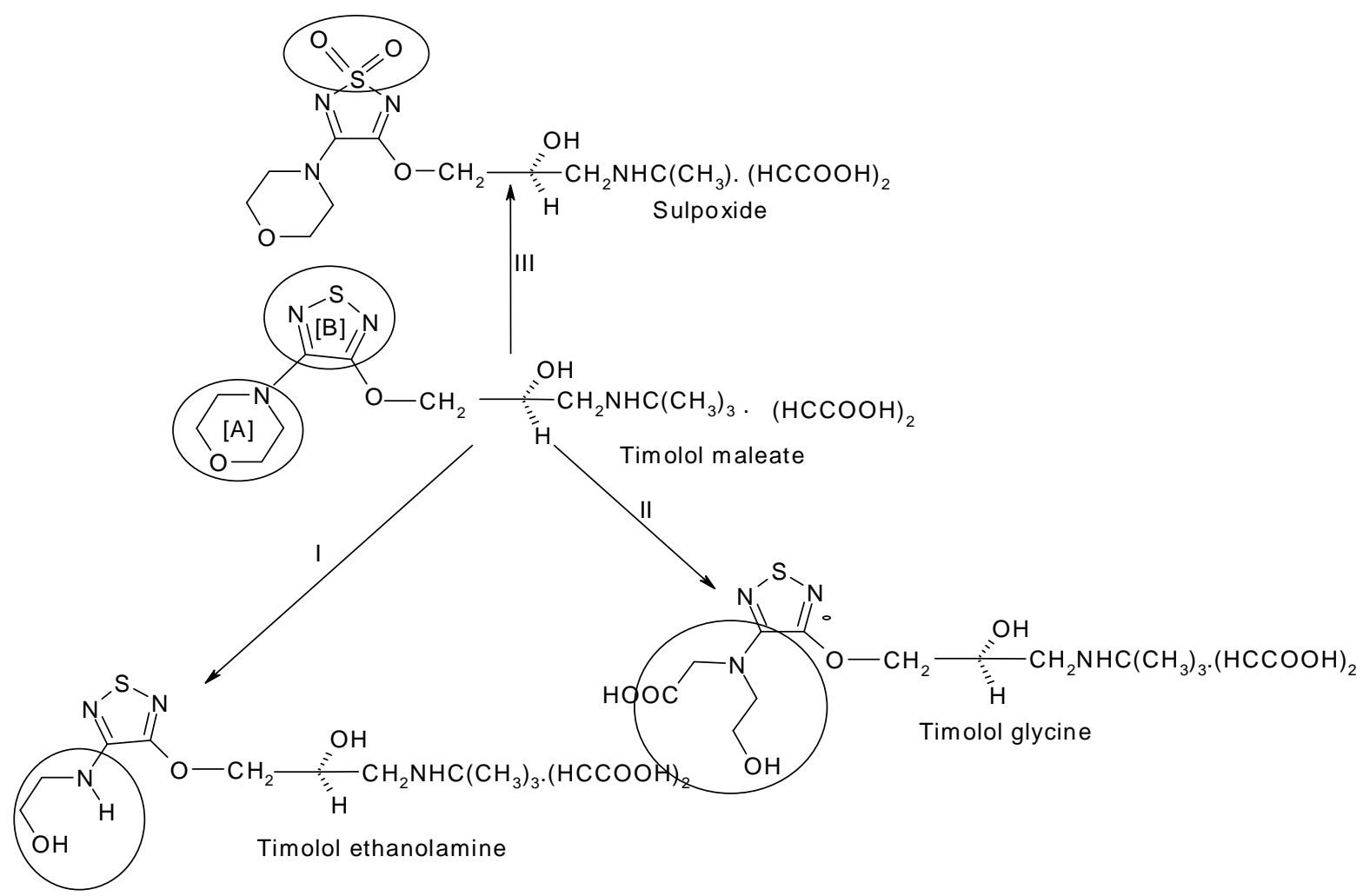

Scheme 1: Proposed oxidation pathways of timolol maleate 
further oxidation would form timolol glycine [23]. The other route (III) involves S-oxidation (sulpoxidation). Theoretically, oxidation of timolol via routes I and II represents in vivo metabolic pathways and the mechanisms have not been established unequivocally [24]. Postulations also revealed that the oxidation pathways cannot be harnessed ex vivo or in vitro quantitatively to warrant its usefulness in the present studies as the metabolism (by oxidation) of several drugs (including metoprolol and timolol) is linked to the debrisoquine oxidation phenotype [24]. Several drugs which possess structures (ring B) similar to timolol have been found to be oxidized quantitatively to its sulphoxide in acidic medium [25] suggesting the possibility of timolol oxidation via such mechanism.
The validation parameters of timolol maleate in this study compare very well with reported parameters of other developed methods, suggesting the suitability of this method in the routine assay of timolol. The UV detection $\Lambda$ differs due to the differences in the methods developed and solvents applied. Theoretically, the sensitivities of some of the earliest developed methods are higher than the present method; however, most of them are too expensive and cumbersome to be used in the routine assay of timolol especially in developing economies where their procurement, expertise and maintenance are difficult to come by.

Table 5: Comparison of validated parameters of timolol assay

\begin{tabular}{|c|c|c|}
\hline Method & Validated assay parameters & Ref. \\
\hline $\begin{array}{l}\text { Chemometric (CLS, } \\
\text { PCR, PLS) }\end{array}$ & $\begin{array}{l}\Lambda_{\max } 295 \mathrm{~nm}, \% \text { mean recovery 99.85, \% S.E 1.0, } \mathrm{R}^{2} \text { 0.9727-0.9993, } \Lambda_{\max } \\
234-377 \mathrm{~nm}, \mathrm{IC}_{95} \text { 93.67-105.75\%. }\end{array}$ & {$[6] \dagger$} \\
\hline $\begin{array}{l}\text { Vierordt's and bivariate } \\
\text { calibration algorithm } \\
\text { spectrophotometry }\end{array}$ & $\begin{array}{l}\Lambda_{\max } 257 \mathrm{~nm} \text {, linearity } 5-85 \mathrm{ppm}, \mathrm{R}^{2} \text { 0.9999, LOD } 1.40-1.47 \mathrm{ppm} \text {, accuracy } \\
99.9-100.3 \% \text {, precision (SD) } 0.702-0.996, \% R S D 0.700-0.967, \% \text { error } 0.221- \\
0.306 \text {, repeatability } 99.7-100.5 \text {, specificity } 100.2-100.6 \% \text {, }\end{array}$ & {$[7] \dagger$} \\
\hline Charge transfer & $\begin{array}{l}\Lambda \max 543 \mathrm{~nm} \text {, linearity } 6.7-24.8 \mathrm{ppm} \text {, molar absorbance } 0.6 \mathrm{l} / \mathrm{mol} . \mathrm{cm}, \mathrm{R}^{2} \\
0.99702 \text {, LOD } 0.129692 \mathrm{ppm} \text {, LOQ } 0.431873 \mathrm{ppm} \text {, precision \% RSD } \\
\text { (interday) 0.349-0.505\% intraday } 0.39-0.78 \% \text {, recovery (serum) } 99- \\
99.332 \% \text {, (urine) } 98.667-99.334 \% \text {, Sandell's sensitivity0.001667 } \mathrm{\mu g} . \mathrm{cm} \text { - } \\
2 / 00.001 \text { A.U }\end{array}$ & {$[17] \dagger$} \\
\hline $\begin{array}{l}\text { Simultaneous equation } \\
\text { method, First Derivative } \\
\text { Method and Ratio First } \\
\text { Derivative UV } \\
\text { spectrophotometry }\end{array}$ & $\begin{array}{l}\Lambda \text { max } 255-294 ; 302.3 ; 290 \mathrm{~nm} \text {, linearity } 2-50 ; \mathrm{ppm}, \mathrm{R}^{2} \text { 0.996-0.998, LOD } 0.24- \\
0.5 ; 0.14 ; 0.091 \mathrm{ppm} \text {, LOQ } 0.1515-0.727 ; 0.424,0.276 \mathrm{ppm} \text {, recovery } 98.94- \\
100.8 ; 99.73-101.1 ; 99.26-100.36 \% \text {, repeatability RSD } 0.369-0.734 ; 1.02 ; \\
0.696 \% \text {, RSD precision (interday) } 0.329-0.940 ; 0.603-1.376 ; 0.388-0.870 \% \\
\text { (intraday) } 0.165-0.722 ; 0.276-0.361 ; 0.298-0.379 \%\end{array}$ & {$[8] \dagger$} \\
\hline TLC-densitometry & $\begin{array}{l}\Lambda \text { max } 294 \mathrm{~nm} \text {, linearity } 1000-6000 \mathrm{ng} / \mathrm{spot} \text {, recovery } 99.87 \% \text {, RSD precision } \\
\text { (intraday) } 0.74-1.42 \% \text { (interday) } 1.15-1.46 \% \text {, recovery } 99.75-99.96 \%\end{array}$ & {$[16]$} \\
\hline RP-HPLC & $\begin{array}{l}\Lambda \text { max } 285 \mathrm{~nm} \text {, linearity } 5-30 \mathrm{ppm} \text {, recovery } 99.75-100.06 \% \text {, LOD } 1.24 \mathrm{ppm} \text {, } \\
\mathrm{LOQ} 3.77 \mathrm{ppm} \text {, robustness RSD } 0.053-0.260 \% \text {, regression } \mathrm{y}=47.28 \times-15.57 \text {, } \\
\mathrm{R}^{2} 0.999 \text {, precision RSD (interday) } 0.04 \text { (intraday) } 0.16 \text {, commercial drug } \\
\text { estimate } 100.42 \% \text {. }\end{array}$ & {$[18] \dagger$} \\
\hline UV spectrophotometry & $\begin{array}{l}\Lambda \text { max } 295 \mathrm{~nm} \text {, linearity } 2-10 \mathrm{ppm} \text {, regression equation } \mathrm{y}=0.0258 \mathrm{x}-0.00076, \mathrm{R}^{2} \\
0.9999, \mathrm{LOQ} 1.0 \mathrm{ppm} .\end{array}$ & [9] \\
\hline RP-HPLC & $\begin{array}{l}\Lambda \max 295 \mathrm{~nm} \text {, linearity } 10-20 \mathrm{ppm} \text {, precision RSD (intraday) } 1.24-1.68 \% \\
\text { (interday) } 1.31-1.86 \% \text {, recovery } 97.3-99.4 \% \text {. LOQ } 1.4 \mathrm{ppm}, \mathrm{R}^{2} 0.989 \text {, } \\
\text { regression equation } \mathrm{y}=35.56 \mathrm{x}-10.49 \text {, LOD } 0.4 \mathrm{ppm} \text {. }\end{array}$ & {$[12]$} \\
\hline RP-HPLC & $\begin{array}{l}\Lambda_{\max } 210 \mathrm{~nm} \text {, linearity } 250-750 \mathrm{ppm}, \text { LOD } 0.3 \mathrm{ppm} \text {, LOQ } 0.8 \mathrm{ppm} \text {, regression } \\
\text { equation } \mathrm{y}=17537.67 \mathrm{x}+59803.88, \mathrm{R}^{2} 0.9994 \text {, precision RSD } 0.09 \% \text {, recovery } \\
99.9-100.1 \% \text {. }\end{array}$ & [20] \\
\hline RP-HPLC & $\begin{array}{l}\Lambda \text { max } 295 \mathrm{~nm} \text {, linearity } 10-30 \mathrm{ppm} \text {, regression equation } \mathrm{y}=16109 \mathrm{x}-48294, \mathrm{R}^{2} \\
0.999, \mathrm{LOD} 0.755 \mathrm{ppm}, \mathrm{LOQ} 2.289 \mathrm{ppm} \text {, precision RSD (intraday) } 0.788 \\
\text { (interday) } 0.366 \text {, recovery } 99.31 \% .\end{array}$ & [19] \\
\hline $\begin{array}{l}\text { Derivative and } \\
\text { derivative ratio } \\
\text { spectrophotometry }\end{array}$ & $\begin{array}{l}\Lambda \text { max } 295 \mathrm{~nm} \text {, linearity } 3-20 \mathrm{ppm} \text {, regression equation } y=0.0394 x-0.002, R^{2} \\
0.99992, \mathrm{LOD} 0.32 \mathrm{ppm}, \mathrm{LOQ} 0.97 \text {, precision } R S D<2 \% \text {. }\end{array}$ & {$[10] \dagger$} \\
\hline $\begin{array}{l}\text { This study } \\
\text { (vanadometric } \\
\text { spectrophotometry) }\end{array}$ & Tables 2-4 & $\dagger$ \\
\hline
\end{tabular}




\section{CONCLUSION}

The developed method is simple, rapid, sensitive, reproducible, accurate and economical for assay of timolol compared to some chromatographic methods earlier developed. The probable mechanism of oxidation is by $\mathrm{S}$ oxidation with little or no contribution from the morpholine ring oxidation. The method should be suitable in quality control and assurance for rapid and routine assay of timolol in pure and dosage formulations.

\section{REFERENCES}

1. Swapnil SS, Amol HK, Madhav NW, Charansingh HG, Bapurao BS, Murlidhar SS. Ammonium metavanadate: an effective catalyst for synthesis of a-hydroxyphosphonates. Arkivoc 2009; 2: 138-148.

2. Takahashi LS, Ana PB, Elisabeth C. Growth performance and energetic metabolism of pacu, Piaractus mesopotamicus (Holmberg, 1887), fed diets supplemented with ammonium metavanadate Aquac. Res., 2006; 37: 1372-7. Doi:10.1111/j.13652109.2006.01577.x.

3. Garmonov SY, Shilova NS, Yakoleva AV, Yusupov RA. Indirect determination of $\mathrm{N}$-acetyltransferase activity using ammonium metavanadate for evaluating isoniazide excretion with human urine. Pharma. Chem. J., 2008: 488-192.

4. Soussi A, Francoise $C$, Jean-Pierre $S$, Abdelaziz AE. Impact of green tea on oxidative stress induced by ammonium metavanadate exposure in male rats. Crit Rev Biol, 2006: 775-784.

5. Hoffman, BB. Catecholamines sympathomimetic drugs and adrenergic receptor Antagonists. In: Goodman and Gilman, editors, The Pharmacological Basis of Therapeutics. 10th ed. USA: McGraw-Hill; 2001; pp 254-255.

6. Ferraro MCF, Castellano PM, Kaufman TS. Chemomeric determination amiloride hydrochloride, atenolol, hydrochlorthiazide and timolol maleate in synthetic mixtures and pharmaceutical formulations. J. Pharm. Biomed. Anal., 2004; 34(1): 305-314.

7. Rizk MS, Merey HA, Tawakkol SM, Sweilam MN. Applicability of bivariate calibration algorithm and vierordt method for simultaneous determination of timolol maleate and brimonidine tartrate in their binary mixture and pharmaceutical dosage form. Int. J. Pharma. Sci. Res., 2014; 5(7): 2631-2641.

8. Desai HH, Captain AD. Three simple validated uv spectrophotometric methods for the simultaneous estimation of timolol maleate and brimonidine tartrate and their comparison using anova. Int. J. Pharma. Res. Anal., 2014; 4(3): 168-177.

9. Mohammedi H, Shyale S, Shanta Kumar SM. Physicochemical characterization, UV spectrophotometric method development and validation studies of timolol maleate. Int. J. Pharm. Sci. Rev. Res., 2011; 6(2): 163-166.

10. Abdel-Hay MH, Gazy AA, Hassan EM, Belal TS. Derivative and derivative ratio spectrophotometric analysis of antihypertensive ternary mixture of amiloride hydrochloride, hydrochlorothiazide and timolol maleate. J. Chin. Chem. Soc., 2008; 55: 971 978.

11. Imad I. Hamdan, Huda Q. Development and Validation of a HPLC Method for Determination of Potential Residual Cortisone Compounds in Timolol Maleate Eye Drops, J. Liq. Chrom. Rel. Tech., 2008; 32: 449467.

12. Arun $P$, Murugesan SK, Nanjaian M. Simultaneous Estimation of Brimonidine Tartrate and Timolol Maleate in Nanoparticles Formulation by RP-HPLC. Int. J. Rec. Adv. Pharm. Res., 2011; 3: 31-36.

13. Du J, Quan J, Wang Y. Chemiluminescence determination of timolol maleate by gold nanoparticles-catalyzed luminol-N-bromosuccinimide system. Talanta. 2012; 90: 117-122.

14. Al-Ghamdi AF. Stripping Voltammetric Determination of Timolol Drug in Pharmaceuticals and Biological Fluids. Amer. J. Anal. Chem., 2011; 2: 174-81.

15. Marini RD, Rozet E, Heyden YV, Ziemons E, Boulanger $B$, Bouklouze A. Nonaqueous capillary electrophoresis method for the enantiomeric purity determination of S-timolol using heptakis(2,3-di-Omethyl-6-O-sulfo)- $\beta$-cyclodextrin: Validation using the accuracy profile strategy and estimation of uncertainty. Journal of Chrom A 1120. 2006: 102111.

16. Jain PS, Khatal RN, Jivani HN, Surana SJ. Development and validation of TLCdensitometry method for simultaneous estimation of brimonidine tartrate and timolol maleate in bulk and pharmaceutical dosage form. J Chromatogr. Sep. Tech., 2011; 2(3): 2-5.

17. Suman $M$, Narasimha Rao $C$, Venkateswarlu $P$. Use of Charge Transfer Complex Formation Reaction in Spectrophotometric Determination of Timolol. Int. J. Engr. Sci. Technol., 2013; 3(4): 704-707.

18. Nagaraju P, Kiran KS, Poornima Ch. Development and validation of RP-HPLC method for the simultaneous estimation of brimonidine tartrate and timolol maleate in combined dosage forms. Asian. J. Chem. Pharm. Res., 2014; 2(1): 58-64.

19. Nagori BP, Maru A, Muysuni P, Gupta S. Method development and its validation for simultaneous estimation of timolol maleate and dorzolamide hydrochloride in as API and in ophthalmic solution dosage form by RP-HPLC. J. Chem. Pharm. Res., 2011; 3(4): 866-874.

20. Rele RV, Mhatre VV, Parab JM, Warkar CB. Simultaneous RP-HPLC determination of latanoprost and timolol maleate in combined pharmaceutical dosage form. J. Chem. Pharm. Res., 2011; 3(1): 138144.

Trop J Pharm Res, December 2015; 14(12): 2228 
21. Agarwal A, Tiwari S, Nagariya K. Method development and its validation for quantitative simultaneous determination of latanoprost, timolol and benzalkonium chloride in ophthalmic solution by RPHPLC. J. Drug Deliv. Ther. 2013; 3(2): 26-30.

22. Mehta J, Patel V, Kshatria N, Vyas N. A versatile $L C$ method for the simultaneous quantification of latanoprost, timolol and benzalkonium chloride and related substances in the presence of their degradation products in ophthalmic solution. Anal. Methods, 2010; 2: 1737-1744.
23. Lennard MS, Ramsay LE, Tucker GT, Woods HF. Protecting the poor metaboliser: clinical consequences of genetic polymorphism of drug oxidation. Pharm. Int., 1983; 4: 61-65.

24. Lennard MS, Lewis RV, Brawn LA, Tucker GT, Ramsay LE, Jackson PR, Woods FH. Timolol metabolism and debrisoquine oxidation polymorphism: a population study. Br. J. Clin. Pharmacol. 1989; 27: 429-434.

25. Basavaiah K, Charan VS. New titrimetric and spectrophotometric methods for the determination of promethazine theoclate using metavanadate. Indian J. Chem. Technol., 2003; 10: 355-362. 